\title{
ПАМЯТНЫЕ ДАТЫ
}

DOI $10.31029 /$ vestdnc79/9

\section{ВЫДАЮЩИЙСЯ УЧЕНЫЙ-КАВКАЗОВЕД}

\section{К 150-ЛЕТИЮ СО ДНЯ РОЖДЕНИЯ БАШИРА ДАЛГАТА}

Выдающийся просветитель, видный ученый в области обычного права, этнологии, этнографии, фольклора народов Кавказа, известный общественный деятель, юрист-правовед Башир Керимович Далгат родился 5 ноября 1870 г. в с. Урахи Даргинского округа.

В девятилетнем возрасте Башира взял к себе во Владикавказ его дядя - врач и известный общественно-политический деятель Магомет Далгат, который затем определил племянника в Ставропольскую классическую гимназию. В годы учебы в гимназии Башир был в числе лучших учеников, проявлял большие способности к филологии и математике.

В 1887 г., будучи учеником седьмого класса Ставропольской гимназии, Башир Далгат во время каникул собирал в с. Урахи материалы по обычному праву даргинцев. На эти материалы Б. Далгата впоследствии ссылался проф. М.М. Ковалевский в своей работе «Закон и обычай на Кавказе».

В 1887-1888 гг. Башир Далгат записывает в с. Урахи даргинский фольклор,

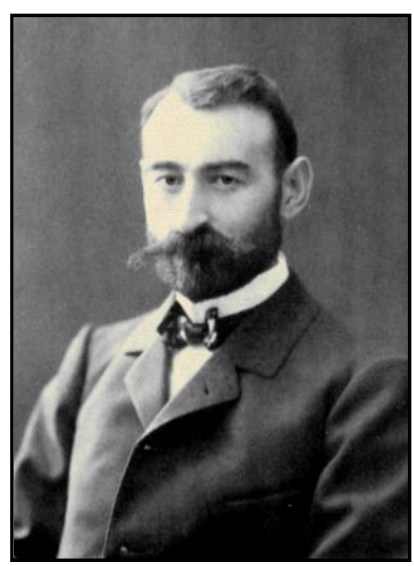
а также песни поэта-лирика Омарла Батырая. В 1888 г. Б. Далгатом были записаны на урахинском и цудахарском диалектах даргинского языка двенадцать цудахарских песен.

В 1889 г. после окончания гимназии Б.К. Далгат поступил на физико-математический факультет СанктПетербургского университета. Однако со второго курса он перевелся на юридический факультет. Б. Далгат в совершенстве знал латынь, греческий и французский языки, помимо родного даргинского он знал и другие дагестанские языки, в частности кумыкский и лезгинский. Во время учебы в университете Башир Далгат совершал экспедиции и экскурсии по Кавказу, собирал фольклорный и этнографический материал. В 1893 г. в «Терском сборнике» был опубликован этнографический очерк Б. Далгата «Первобытная религия чеченцев». В 1905-1906 гг. в нескольких номерах газеты «Весь Кавказ» публикуются отрывки из его большой работы «Родовой быт чеченцев и ингушей».

В 1895 г. Башир Далгат окончил Санкт-Петербургский университет и получил диплом высшей степени и звание кандидата прав. Тогда же он приехал во Владикавказ, где жил примерно до 1920 г. После установления советской власти и объявления Терской области Терской Советской Республикой в составе РСФСР Ингушский народный совет избрал Б. Далгата членом Владикавказского окружного народного суда. В начале 1920 г. он стал заведующим отделом юстиции в Назрановском окружном революционном комитете.

В ноябре 1920 г. Башир Далгат был командирован представителем Реввоенсовета и Промбюро юговостока России в Дагестан для восстановления Хпекского ртутного рудника. Осенью 1922 г. Б. Далгат был назначен юрисконсультом Дагестанского Центрального Исполнительного Комитета, Совнаркома и Экономического совета, а затем - заведующим отделом законодательных предложений Народного комиссариата юстиции и с 20 ноября 1922 г. до 1 мая 1927 г. работал при ЦИКе и Совнаркоме ДАССР.

Являясь сотрудником Дагестанского научно-исследовательского института национальной культуры, Башир Далгат выступал на различных научных конференциях с научными докладами и сообщениями. Он подготовил к печати свои труды по обычному праву даргинцев, обычному праву и родовому строю народов Дагестана, сборник даргинского фольклора.

Башир Керимович Далгат был одним из образованнейших людей своего времени.

Б.К. Далгат умер в 1934 г. в возрасте 63 лет в расцвете творческих сил после тяжелой болезни. Похоронен в городе Махачкале.

P.И. Сефербеков, ORCID: 0000-0002-0901-8499, доктор исторических наук, главный научный сотрудник Института истории, археологии и этнографии ДФИЦ РАН. 